\title{
Can conservation and development really be integrated?
}

\author{
Jeffrey Sayer
}

\author{
Forest Conservation Programme IUCN \\ 28 rue Mauverney, 1196 Gland, Switzerland \\ Phone: +41229990120 \\ E-mail: jeff.sayer@iucn.org \\ www.iucn.org
}

\begin{abstract}
Most biodiversity conservation projects in poor tropical countries also aspire to alleviate the poverty of local people. The results of these integrated conservation and development projects have often been disappointing. This paper argues that it would be impossible for both practical and ethical reasons for conservation programmes to ignore the needs of poor people who live in and around the natural areas that we seek to conserve. The problem is not whether we should attempt to integrate conservation and development but rather how we should attempt to do so. Recommendations are made for a number of principles that should underlie such programmes. It is argued that they should operate at the scale of landscape mosaics, they should be firmly rooted in local social processes and they should make the tradeoffs between conservation and development explicit. Less effort should go into planning them and more into working with local stakeholders to explore options and find solutions that meet both local livelihood needs and global conservation goals.
\end{abstract}

\section{RÉSUMÉ}

La plupart des projets qui portent sur la conservation de la biodiversité dans les pays pauvres distribués sous les tropiques tentent également d'améliorer la qualité de vie des populations riveraines. Les résultats de ces projets «intégrés» ont cependant souvent été décevants. Dans cet article je prends position pour défendre que pour des raisons à la fois pratiques et éthiques il serait insensé de ne pas prendre en compte les intérêts des populations directement impliquées dans ces programmes intégrés de protection de la biodiversité. La question n'est pas simplement de les impliquer ou ne pas les impliquer mais il s'agit davantage d'identifier de nouveaux modèles pour que leur implication devienne réalité. La conservation et le développement sont inéluctablement liés et ne peuvent pas être considérés comme deux entités distinctes. Je propose ainsi quelques principes de bases à respecter dans ces programmes intégrés afin d'assurer les meilleurs chances de réussite. Ces programmes devraient intervenir à l'échelle des territoires qui abritent les biotopes des espèces à protéger ainsi que les zones occupées ou exploitées par les populations locales. Ils devraient trouver leurs racines au plus profond de la dynamique des sociétés concernées et être en mesure de montrer clairement les impacts des actions de conservation sur les moyens d'existence des peuples. II s'agirait ainsi de réduire les interventions d'experts extérieurs dans la planification pour favoriser et encourager la recherche d'alternatives et de solutions concertées avec les acteurs locaux pour réussir aussi bien à protéger la nature qu'à améliorer les conditions de vie des populations humaines.

KEYWORDS: Conservation, development, landscape, livelihoods, biodiversity.

MOTS CLEF : conservation, développement, paysage, subsistance, biodiversité.

\section{INTEGRATING CONSERVATION AND DEVELOP- MENT}

Madagascar is a country with high levels of poverty - at least as defined by development assistance agencies. It is also home to biodiversity that is valued as a global resource. As a result a lot of the conservation initiatives in the country are invested in attempts to simultaneously address the two distinct problems of alleviating poverty and conserving biodiversity. There is now a growing skepticism as to whether these integrated approaches really work. This paper argues that integrating conservation and development is more important than ever. The lack of success in the past stemmed from the attempts to achieve the integration through externally imposed projects constrained by the procedures of the external actors who funded them. Although most conservation and development agencies espouse the virtues of locally driven processes few of them actually practice what they preach.

Throughout the world the integration of conservation and development has been the mantra of conservation organizations for more than four decades. Integrated approaches were first motivated by the belief that traditional agricultural practices and poaching were the overriding threat to the preservation of tropical nature. Modernizing peasant agriculture, linking the poor to the market economy, giving them land rights and introducing new agricultural technologies were all seen as key to improving their livelihoods whilst at the same time reducing their demands for new land. Up until the late 1980s and early 1990s the conventional conservation wisdom was that the major threat to tropical forests came from shifting agriculture.

More recent studies have shown that it was wrong to blame all the problems on shifting agriculture (Geist and Lambin 2002). There were places like eastern Madagascar, where tavy was, and remains, a real problem for the maintenance of natural forests, 


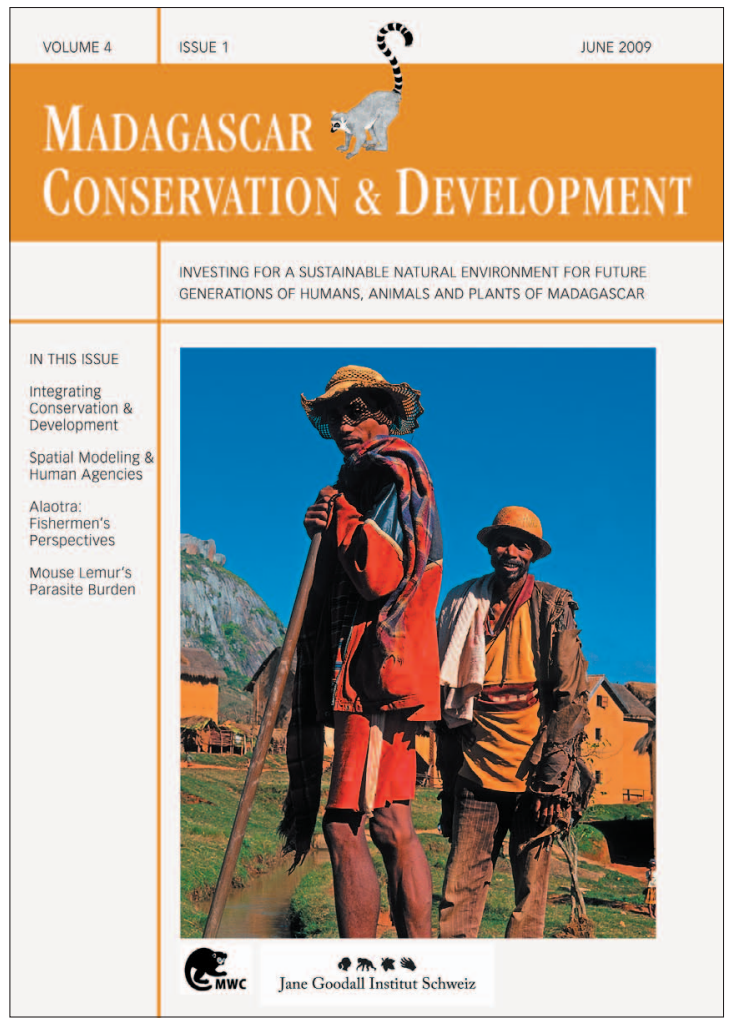

Madagascar Conservation \& Development is the journal of Madagascar Wildlife Conservation (MWC) and the Jane Goodall Institute (JGI Switzerland). It is produced in these institutions' own responsibility.

All the Issues and articles are freely available at http://www.mwc-info.net/en/services/journal.htm

Contact Journal MCD

info@journalmcd.net for general inquiries MCD funding@journalmcd.net for supporting the journal

Journal Madagascar Conservation \& Development Institute and Museum of Anthropology University of Zurich

Winterthurerstrasse 190

$\mathrm{CH}-8057$ Zurich, Switzerland

contact@mwc-info.net for general inquiries

Postfach 2701

CH-8021 Zürich, Switzerland

Logement 11, Cité Andohaniato Antananarivo 101, Madagascar

info@janegoodall.ch for general inquiries JGI

$2 \pi \approx$

Jane Goodall Institut Schweiz
Jane Goodall Institute Schweiz

Postfach 2807

8033 Zürich

Switzerland 
but in many parts of the world long-cycle shifting agriculture was nowhere near as damaging to nature as was often claimed Amongst some environmental groups logging was also portrayed as a major threat but there is little evidence that logging alone has ever done much permanent harm to tropical forests (Pearce et al. 2003). Logging has been a problem when associated with demand for agricultural land and more significantly as a driver of corruption and bad governance but logging alone did not destroy forests. Recent studies by FAO and others confirm that most tropical deforestation is planned conversion to things like soybeans in the Matto Grosso, oil palm in southeast Asia or tree crops in West Africa. Most scenarios for the tropics see large-scale development of agro-industries to feed the world's projected population of 9 billion meat eating, car driving, middle class citizens as the main future threat to nature.

one can debate whether the demand for tropical products by the rich world is a threat or an opportunity for tropical biodiversity and the livelihoods of rural people. Expanding demand for food and biofuels certainly increases pressure for land conversion but it also creates jobs and increases incomes so that rural people can invest in more efficient and intensive agriculture. Increased external demand in a context of good local governance is probably positive but when there are governance failures and corruption is rife then market pressures can be very damaging.

In the days when we thought that people destroyed nature to meet their subsistence needs it made a lot of sense to work with populations around critical natural areas to improve the productivity of their farming. Bee keeping, agro-forestry, non-timber forest products all offered plausible ways of sustaining livelihoods without destroying more forests (Roe and Elliott 2008). The problem was that the rural poor were not satisfied with simply sustaining their existing livelihoods; they wanted to escape from their subsistence ways of life. They wanted better education for their children; better health care; and jobs and income so that they could enjoy some of the benefits that they observed in the rich world. Continuing to subsist but in a slightly more environmentally friendly way, the eco-development paradigm, did not meet their expectations. If they were aware of a new technology that showed promise of being profitable then their zeal for clearing forest was intensified. When people discovered booming markets for the cinnamon produced in Sumatra they redoubled their efforts to clear forest in Kerinci National Park. When raising cattle was profitable in the Amazon then landless people invaded the forest and established ranches (Kaimowitz et al. 2005). Their investment costs were low and securing de facto title to the land was an important motivating factor.

Most rigorous studies of attempts to address conservation problems through local eco-development interventions, for instance in buffer zones around critical areas, have concluded that there was little evidence that they did much either for local livelihoods or for conservation (McShane and Wells 2004). There is circumstantial evidence that in many cases these projects may even have created local poles of development activity that increased the pressure on natural areas. In many parts of the tropics the pressure has only been taken off forests when people have found it more attractive to move to the cities to work in services or factories. The manufacturing boom of the 1980s and 1990s in southeast Asia did more to eliminate shifting agriculture than any attempt at integrating conservation and development. However the basic problem remains that people will always clear forest when it is profitable to do so. Profitability is determined by the likelihood of making money versus the likelihood of being punished for illegal land clearing.

In 2008-9 the world entered a food crisis. Prices of commodity crops rose dramatically and once again there were predictions of famine on a grand scale. The yield gains obtained by the 'green revolution' are not being maintained and many see the solution to the world's food problems as lying in massive expansion of agriculture into forest lands, especially in Africa. Most of this expansion will have to be into areas previously considered marginal for conventional agriculture but where improved crop varieties and modern farming technologies, fertilizers and pesticides now make agriculture possible. This pressure for more land will come at a time when huge investments are planned to put infrastructure into the remotest corners of the tropical world. New roads and railways are being built to give access to minerals, timber and hydroelectric schemes or simply to facilitate the rule of law in remote areas. This burgeoning infrastructure will greatly increase the profitability of agriculture in hitherto inaccessible areas and a vicious circle of forest destruction is likely to follow. In the face of these challenges our traditional approaches to integrating conservation and development will be totally inadequate.

There is a strong body of opinion that in the face of such growing threats and in recognition of the poor performance of ICDPS (Integrated Conservation and Development Projects) we must fall back on fortress conservation or 'fences and fines'. It is argued that conservation money should be invested in strictly protected areas and law enforcement. However, I would like to align myself with many others who argue that this would be a mistake (for example Wilshusen et al. 2002). The challenges we are facing require more than ever that conservation and development be integrated (Wells et al. 2004). But this integration must be in new ways and at different scales (Sayer et al. 2008).

\section{PRINCIPLES FOR NEW APPROACHES TO INTE- GRATING CONSERVATION AND DEVELOPMENT} I would offer the following principles for future endeavors:

WORK AT LARGE SPATIAL SCALES - OPERATIONALISE THE

LANDSCAPE CONCEPT Attempting to alleviate poverty by working at a very local scale with the small numbers of people who live in and around features of conservation concern is unlikely to be effective. Such interventions may be useful in building social capital and defusing tensions and even in learning about the area by tuning in to local knowledge. But significant improvements in livelihoods rarely come from marginal improvements to existing livelihood practices; they almost always come from the new opportunities presented by external investment, new infrastructure and access to markets. To improve livelihoods one should not focus on what the poor are doing now but on what they might do in the future in growing economies. Macro-level changes in investment and infrastructure drive development not incremental changes in subsistence livelihood practices. Sacrificing some natural habitat for an agro-industrial plantation will do far more to alleviate poverty than marginal improvements in agro-forestry or non-timber forest product systems (see for instance Sandker et al. 2007). Understanding 
the underlying drivers of change and the potential routes out of poverty is essential and this is best achieved at a landscape scale - that is to say a scale that includes a diversity of landscape elements and includes natural habitats, agricultural and industrial areas. Conservation programmes must be set in the context of the most probable changes in the social-ecological system and not based upon an idealized plan that does not recognize the real aspirations of people.

LANDSCAPES AND CATCHMENTS ARE OFTEN APPROPRIATE

SCALES Working at these larger scales forces one to cut across sectoral boundaries and to engage with a broader diversity of stakeholders. It also helps to understand broader developmental trajectories and to focus on the big issues and not the local and marginal. Landscapes are the right scales at which to engage with civil society and to develop the social movements that can underpin efforts to achieve sustainability. Landscapes encompass all of the elements that contribute to people's livelihoods - both from their farms and from surrounding forests. People are often making extensive use of lands that are the habitats of the species of conservation concern. New decentralized natural resource management arrangements often fit in nicely with the landscape scale. Lastly, within a landscape there is room to manœuvre - losses in one part of a landscape may be offset against gains elsewhere. The Adapting Mosaic scenario developed under the Millennium Ecosystem Assessment provides a good conceptual framework for landscape scale interventions (Millennium Ecosystem Assessment 2005).

LISTEN, LEARN AND ENGAGE WITH STAKEHOLDERS

Expert missions that parachute in, conduct diagnostic stud ies and prescribe solutions are a sure recipe for failure. It takes time and patience to become attuned to the real issues in a complex conservation landscape. The principles of 'appreciative enquiry' provide useful guidance on how to engage with local populations (Cooperrider et al. 1995). Stakeholder meetings are needed and consensus must be built but it is risky to jump too quickly into setting up formal stakeholder platforms. Dealing with the conflicting interests of diverse groups can be difficult. It is better to start with a smaller number of sympathetic local stakeholders and gradually expand the network as opportunity and needs arise. There is a common myth that simply convening a large group of people with conflicting interests will lead rapidly to consensus on win-win outcomes. Win-wins are rare and one is usually seeking simply to win a little more and lose a little less. Stakeholder platforms are important but outsiders have to invest a lot of time in really understanding the dynamics of local interactions and how local behaviors might be changed.

EXPLORE SCENARIOS An excellent way of engaging

with stakeholders and sharing understanding of potential change is to explore those scenarios for the future that would meet their developmental needs whilst also achieving conservation. Using simple drawing exercises where different stakeholders draw their best and worst case future scenarios provide a very good entry point for discussions. If skilled facilitation is available then building simple simulation models to explore scenarios in a more quantitative and rigorous way can be valuable. Both visualization techniques and modeling often produce counter-intuitive results (van den Belt 2004).

IDENTIFY INDICATORS Working with local stakeholders to

identify simple indicators of progress towards the preferred scenario is very effective in focusing debate and providing feedback for adaptive management (Bell and Morse 1999). Indicators should sit in a framework that covers both environment and development. The capital assets framework has been used with success at a landscape scale. It allows trade-offs between losses of natural capital and gains in human, social and built capital to be assessed and negotiated (Sayer et al. 2006). Reed et al. (2008) provide a compelling rational for working through local people to derive indicators.

DO NOT PLACETOO MUCHEMPHASIS ON FORMAL PLANNING

Having clarity on the overall goal of an intervention is essential (Lee 1993). But it is a mistake to lock-in too early to a specific pathway to that goal. Maps and plans prepared by experts can look very convincing but they can also mask numerous assumptions and can exclude important realities of local people. Seeking solutions rather than developing blue-prints provides a better route forward in any development activity (Easterly 2008). Muddling through provides a better conceptual basis for engagement than detailed design (Sayer et al. 2008).

BASE CONSERVATION PLANS ON DESIRED OUTCOMES NOT

PERCEIVED THREATS Conservation often focuses on protecting pristine nature against external threats. Threat-based conservation places conservationists in a permanently defensive mode of operation and is difficult to reconcile with the pursuit of a development agenda. It is better to take an outcome-based approach and work towards sets of outcomes that will provide an optimal balance between conservation and development benefits. Negotiated agreement on desired scenarios provide the best basis for moving forward but one has to recognize that these are complex systems and constant adaptation and course adjustment will be needed (Sayer and Campbell 2004, Sayer and Maginnis 2005).

SET REALISTIC GOALS FOR BIODIVERSITY Seeking to conserve all biodiversity is often not a realistic objective. In most landscape mosaics inhabited by poor people development will inevitably cause some losses of biodiversity. Not all biodiversity has equal value and not all can be maintained. Setting realistic, measurable and locally relevant biodiversity objectives will provide a sound basis for the negotiation of trade-offs. Even the Convention on Biodiversity in its Ecosystem Principles recognizes that biodiversity conservation must be a question of societal choice - with local societies having an important influence on the decisions. It is important to recognize that local people may have their own priorities for biodiversity that differ from those of outside conservation groups. Building on these may provide a sound basis for securing local buy-in (Sheil et al. 2006). It is also important to recognize that sustainable use of biodiversity may be a more attractive option for local people than total protection. If people can benefit from using a species they are more likely to conserve it

CHOOSE LEADERS OF INTEGRATED CONSERVATION AND DEVELOPMENT PROGRAMMES WITH THE RIGHT QUALITIES Perhaps my overarching set of suggestions concerns the attitude and competencies of the leaders of conservation programmes. There is a tendency for programme leaders to be selected on the basis of their ability to deal with donor requirements. Someone who is good at log-frames and spread sheets will be preferred to someone who is happy to live in the local community and learn the local language. The success or failure of projects depends very heavily on the competence, sensitivity and adaptability of the programme leader. Table 1 contrasts the qualities that have 
TABLE 1. The qualities needed to lead conservation and development initiatives

\begin{tabular}{|l|l|}
\hline \multicolumn{1}{|c|}{ Old paradigm } & \multicolumn{1}{c|}{ New paradigm } \\
\hline $\begin{array}{l}\text { Analysis and Diagnosis of the } \\
\text { situation }\end{array}$ & Listening and learning \\
\hline Planning & Seeking \\
\hline Spatial plans and maps & Scenarios \\
\hline Teaching and persuading & $\begin{array}{l}\text { Sharing experiences and learning } \\
\text { together }\end{array}$ \\
\hline Setting goals and targets & Exploring options \\
\hline Managing and controlling & $\begin{array}{l}\text { Creating space for others and } \\
\text { facilitating }\end{array}$ \\
\hline Monitoring and evaluations & Seeking feedback \\
\hline Fixed end point & Adapting mosaic \\
\hline Sustainability & Resilience \\
\hline Hiding mistakes & Learning from mistakes \\
\hline
\end{tabular}

traditionally been sought in programme leaders under a conventional development paradigm and suggests an alternative profile for a new paradigm.

\section{CONCLUSIONS}

For both practical and ethical reasons conservation practitioners must continue to engage with local stakeholders and they must learn to see conservation situations through the eyes of the people most directly impacted by their actions. Although many projects that sought to reconcile conservation and development have yielded disappointing results there are also many examples where committed individuals have achieved success. They have usually been people who have made a long-term commitment to seeking conservation and development outcomes for a critical area or species. These people have worked pragmatically with local communities because that was where they found problems and opportunities. They have muddled through, often liberated by the absence of the constraints imposed by the rigid frameworks of development-assistance donors. These champions of conservation and development have often found common ground with local stakeholders and have been able to bring about a convergence of interests. I started this essay with the rhetorical question of whether it is time to give up on attempting the integration of conservation and development. My answer is an emphatic no. We must continue to seek to integrate conservation and development. But not in the form of pre-planned, time bound projects but rather through long-term engagement with the people whose livelihoods are intimately connected to the natural resources being conserved.

\section{REFERENCES}

Bell, S. and Morse, S. 1999. Sustainability Indicators: Measuring the Immeasurable? Earthscan, London.

Cooperrider, D. L., Barrett, F. and Srivastva, S. 1995. Social construction and appreciative inquiry: A journey in organizational theory. In: Management and Organization: Relational Alternatives to Individualism. D. Hosking, P. Dachler and K. Gergen (eds.), pp 157-200. Avebury Press, Aldershot, UK.

Geist, H. J. and Lambin, E. F. 2002. Proximate causes and underlying driving forces of tropical deforestation. Bioscience 52, 2: 143-150. (doi:10.1641/0006-3568(2002)052[0143:PCAUDF]2.0.CO;2)
Kaimowitz, D., Byron, R. N. and Sunderlin, W. D. 2005. Public policies to reduce inappropriate tropical deforestation. In: The Earthscan Reader in Forestry and Development. J. Sayer (ed.), pp 239-263. Earthscan, London.

Lee, K. 1993. Compass and Gyroscope: Integrating Science and Politics for the Environment. Island Press, Washington D. C.

McShane, T. O. and Wells, M. P. (eds.) 2004. Getting Biodiversity Projects to Work: Towards More Effective Conservation and Development. Columbia University Press, New York.

Millennium Ecosystem Assessment. 2005. Ecosystems and Human WellBeing, volume 2, Scenarios. Island Press, Washington DC. <http://www. millenniumassessment.org/en/Scenarios.aspx> accessed 28th January 2008.

Pearce, D., Putz, F. E. and Vanclay, J. K. 2003. Sustainable forestry in the tropics: Panacea or folly? Forest Ecology and Management 172, 2-3: 229-247. (doi:10.1016/S0378-1127(01)00798-8)

Reed, M. S., Dougill, A. J. and Baker, T. R. 2008. Participatory indicator development: What can ecologists and local communities learn from each other. Ecological Applications 18, 5: 1253-1269. (doi:10.1890/07-0519.1)

Roe, D. and Elliott, J. 2008. Poverty reduction and biodiversity conservation: Rebuilding the bridges. Oryx 38, 2: 137-139. (doi:10.1017/ S0030605304000249)

Sandker, M., Suwarno, A. and Campbell, B. M. 2007. Will forests remain in the face of oil palm expansion? Simulating change in Malinau, Indonesia. Ecology and Society 12, 2: 37 . Also available at <http://www.ecologyandsociety.org/vol12/iss2/art37/>.

Sayer, J. A. and Campbell. B. 2004. The Science of Sustainable Development: Local Livelihoods and the Global Environment. Cambridge University Press, Cambridge, U. K. and New York.

Sayer, J. A. and Maginnis, S. (eds.) 2005. Forests in Landscapes: Ecosystem Approaches to Sustainability. Earthscan, London.

Sayer, J., Campbell, B., Petheram, L., Aldrich, M., Ruiz Perez, M., Endamana, D., Nzooh Dongmo, Z.-L., Defo, L., Mariki, S., Doggart, N. and Burgess, N. 2006. Assessing environment and development outcomes in conservation landscapes. Biodiversity and Conservation 16, 9: 2677-2694. (doi:10.1007/s10531-006-9079-9)

Sayer, J., Bull, G. and Elliott, C. 2008. Mediating forest transitions: 'grand design' or 'muddling through'. Society and Conservation 6, 4: 320-327.

Sheil, D., Puri, R., Wan, M., Basuki, I., van Heist, M., Liswanti, N., Rukmiyati, Rachmatika I. and Samsoedin, I. 2006. Recognizing local people's priorities for tropical forest biodiversity. Ambio 35, 1: 17-24. (doi:10.1579/0044-7447-35.1.17)

van den Belt, M. 2004. Mediated Modeling: A System Dynamics Approach to Environmental Consensus Building. Island Press, Washington D. C.

Wells, M. P., McShane, T. O., Dublin, H. T., O'Connor, S. and Redford, K. H. 2004. The future of integrated conservation and development projects: Building on what works. In: Getting Biodiversity Projects to Work: Towards More Effective Conservation and Development. T. O. McShane and M. P. Wells (eds.), pp 397-422. Columbia University Press, New York.

Wilshusen, P. R., Brechin, S. R., Fortwangler, C. L. and West, P. C. 2002 Reinventing a square wheel: Critique of a resurgent "protection paradigm" in international biodiversity conservation. Society \& Natural Resources 15, 1: 17-40. (doi:10.1080/089419202317174002) 